\title{
The cost of one unit blood transfusion components and cost-effectiveness analysis results of transfusion improvement program
}

\author{
Kan bileşenleri birim transfüzyon maliyeti ve transfüzyon iyileştirme programının \\ maliyet etkinlik analiz sonuçları
}

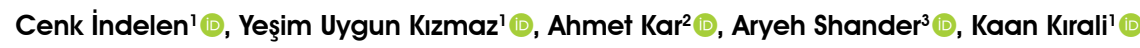 \\ Institution where the research was done: \\ Kartal Koşuyolu High Specialization Education and Research Hospital, Istanbul, Turkey
}

\author{
Author Affiliations: \\ 'Department of Cardiovascular Surgery, Kartal Koşuyolu High Specialization Education and Research Hospital, Istanbul, Turkey \\ ${ }^{2}$ Department of Health Management, Kırıkkale University Faculty of Health Sciences, Kırıkkale, Turkey \\ ${ }^{3}$ Department of Anesthesiology and Reanimation, Englewood Hospital \& Medical Center, New Jersey, USA
}

\begin{abstract}
Background: This study aims to analyze the cost of the entire transfusion process in Turkey including evaluation of the cost of transfusion from the perspective of hospital management and determination of savings achieved with the transfusion improvement program.

Methods: Invoices, labor, material costs were calculated with micro-costing method, while general production expenses were calculated with gross costing method between January 2018 and December 2019. Unit costs for each blood product were calculated separately by collecting unit acquisition costs, material costs, labor costs, and general production expenses and, then, distributed into six different blood products as follows: erythrocyte suspension, fresh frozen plasma, pooled platelet, apheresis platelet, cryoprecipitate, fresh whole blood. The total costs for 2018 and 2019 were calculated and the savings achieved were estimated. The Turkish Lira was converted into the United States Dollar (\$) currency using the purchasing power parity.

Results: In 2018/2019, the blood component transfusion cost was $\$ 240.90 / 251.18$ for erythrocyte suspension, $\$ 120.00 / 128.67$ for fresh frozen plasma, $\$ 313.50 / 322.19$ for pooled platelet, $\$ 314.24 / 325.73$ for apheresis platelet, $\$ 104.95 / 113.99$ for cryoprecipitate, and $\$ 189.91 / 209.09$ for fresh whole blood. The total transfusion cost was $\$ 6,224,208.33$ in 2108 and $\$ 5,308,148.43$ in 2019. As a result of the transfusion improvement program launched in 2019 , the amount of blood components decreased by $23.24 \%$, compared to the previous year, and a saving of $\$ 916,059.9$ was achieved.

Conclusion: The transfusion is a burden for both the hospital management systems and the country's economy. To accurately calculate and manage this economic burden is important for sustainable healthcare services.

Keywords: Cost, cost-effectiveness, patient blood management, transfusion, transfusion improvement program.
\end{abstract}

\section{$\ddot{O} Z$}

Amaç: Bu çalışmada hastane yönetiminin perspektifinden transfüzyon maliyetinin değerlendirilmesi ve transfüzyon iyileştirme programı ile elde edilen tasarrufların tespit edilmesi dahil olmak üzere, Türkiye'de tüm transfüzyon sürecinin maliyeti analiz edildi.

Çalışma planı: Ocak 2018-Aralık 2019 tarihleri arasında faturalar, personel ve malzeme maliyetleri mikro maliyetlendirme yöntemi ile genel üretim maliyetleri ise brüt maliyetlendirme ile hesaplandı. Her kan ürününün birim maliyeti; birim alım maliyeti, malzeme maliyeti, personel maliyeti ve genel üretim maliyeti toplanarak ayrı ayrı hesaplandı ve ardından şu altı kan ürününe dağıtıldı: eritrosit süspansiyonu, taze donmuş plazma, havuzlanmış trombosit, aferez trombosit, kriyopresipitat ve taze tam kan. 2018 ve 2019 yıllarına ait toplam maliyet hesaplandı ve sağlanan tasarruf ölçüldü. Türk Lirası, satın alma gücü paritesi kullanılarak Amerika Birleşik Devletleri Dolar kuruna (\$) çevrildi.

Bulgular: 2018/2019 yıllarında kan bileşeni transfüzyon maliyeti sırasıyla eritrosit süspansiyonu için $240,90 / 251,18$, taze donmuş plazma için $120,00 / 128,67 \$$, havuzlanmış trombosit için $313,50 / 322,19 \$$, aferez trombosit için $314,24 / 325,73 \$$, kriyopresipitat için $104,95 / 113,99$ ve taze tam kan için 189,91/209,09\$ idi. Toplam transfüzyon maliyeti 2018 y1lında 6.224.208,33\$ ve 2019 yllinda 5.308.148,43\$ idi. 2019 yılında başlatılan transfüzyon iyileştirme programı sonucunda, bir önceki yıla kıyasla, kan ürünü miktarı \%23.24 oranında azalarak, 916.059,9\$ tasarruf sağlandı.

Sonuç: Kan transfüzyonu hem hastane yönetim sistemleri hem de ülke ekonomisi için bir yüktür. Bu ekonomik yükü doğru bir şekilde hesaplamak ve yönetmek, sürdürülebilir sağlık hizmetleri için önemlidir. Anahtar sözcükler: Maliyet, maliyet etkinliği, hasta kan yönetimi, transfüzyon, transfüzyon iyileştirme programı.

Received: October 14, 2020 Accepted: January 20, 2021 Published online: April 26, 2021

Correspondence: Cenk İndelen, MD. Kartal Koșuyolu Yüksek intisas Eğitim ve Araştırma Hastanesi, Kalp ve Damar Cerrahisi Kliniği, 34865 Kartal, istanbul, Türkiye. Tel: +90532-4475413 e-mail: cindelen@gmail.com 
It is important to evaluate the cost and suitability of diagnosis and treatment methods for the sustainability of health services according to quality standards. With the advances in medical technology, hospitals have become socioeconomic institutions, constituting a significant part of health expenditures. $^{[1,2]}$ Hospital cost accounting is an information system that records and reports financial information on health services with its techniques. The main purpose of this system is to determine unit costs and to assist in cost control, planning, and decision making. ${ }^{[3]}$ Studies which shed light into the financial decisions of hospital managers are called hospital cost analysis. ${ }^{[4]}$

Allogeneic blood transfusion causes variable costs according to different applications in treatment expenditures. $^{[5]}$ It imposes an economic burden to purchase, test and prepare the component suitable for transfusion, deliver blood components to relevant clinics, apply to the recipient, monitor, treat transfusion-induced reactions, disposal of it as medical waste, and file all mandatory information.

Hospitals are not standard manufacturing companies; therefore, the cost calculation of hospitals involves more complex processes. In a cost analysis study, the spectrum is among the bottom-up (micro-costing) and the top-down (gross costing) approach. ${ }^{[6]}$ Each component of resources used in the micro-costing method (such as laboratory tests, medications, or labor hours) is determined and the unit cost is derived from each. It is a frequently used method to calculate the costs more precisely where there is an inventory of all resources used. However, there is no single micro-costing methodology. The methodology used may differ depending on the data set and the objective of the study. The data collected in this context can include administrative data sets, patient charts, hospital accounting systems, or direct observation results. ${ }^{[7]}$ A hybrid model including micro-costing and gross costing methods can also be used in cost calculations. ${ }^{[6]}$

It is a complex process to calculate the cost of the blood transfusion process, regardless of which costing method is used. To calculate the exact cost of the transfusion process, it is first necessary to know the transfusion cost of the "1 Unit" blood component. In this study, we aimed to analyze the cost of the entire transfusion process in Turkey including evaluation of the cost of transfusion from the perspective of hospital management and determination of saving achieved as a result of the improved transfusion process efforts.

\section{PATIENTS AND METHODS}

This retrospective study was conducted at Kartal Koşuyolu High Specialization Education and Research Hospital with a bed capacity of 465 , by calculating the costs of blood components used in all clinics between January $1^{\text {st }}, 2018$ and December $31^{\text {st }}, 2019$. In this study, the total cost of six different blood components including erythrocyte suspension (ES), fresh frozen plasma (FFP), pooled platelet (PT), apheresis platelet (AP), cryoprecipitate (CRY), fresh whole blood (FWB) was calculated. The study protocol was approved by the Kartal Koşuyolu High Specialization Education and Research Hospital Ethics Committee (No: 2020.4/05-310).

In our center, thoracic surgery and oncological colorectal surgery are performed along with surgical and medical cardiovascular interventions. The hospital has a closed area of $41,249 \mathrm{~m}^{2}$ and the transfusion center has an area of $450 \mathrm{~m}^{2}$. While 22,444 patients were hospitalized in 2018, a total of 4,616 surgeries and 24,495 catheters were performed, and emergency service was provided to 69,288 patients. In 2019, 22,270 patients were hospitalized, a total of 5,123 operations, 20,413 catheters were performed, and emergency service was provided to 72,193 patients. ${ }^{[8]}$

Each main process was defined along the transfusion chain, the frequency and utilization characteristics of these processes were determined, the sub-activities of each main step were established, and the time required for these activities was calculated. The unit cost of each blood component was calculated by adding up the material cost, labor cost, and general production cost caused by each activity. The currency of Turkish Lira (") was converted to United States (US) Dollars (\$) using purchasing power parities; i.e., rates of currency conversion eliminating price differences between countries. As a result, a sum of money would have the same buying power in each country. Exchange rates declared by the Organisation for Economic Co-operation and Development (OECD) for 2018 and 2019 years were used in this conversion. A retrospective hybrid model was used, where labor and material costs were calculated by micro-costing and general production costs by gross costing. The calculation methods of these costs were based on the following four items:

1. Acquisition cost: There is no purchase cost for the blood component as only fresh whole blood from the Turkish Red Crescent is prepared in the hospital. For other blood components, a fee is paid to the Red Crescent by the hospital according to the amount of the components (delivered or used). 
Table 1. Procurement and raw material costs (\$)

\begin{tabular}{|c|c|c|c|c|c|c|c|c|c|c|c|c|}
\hline & \multicolumn{6}{|c|}{2018} & \multicolumn{6}{|c|}{2019} \\
\hline & ES & FFP & PP & AP & CRY & FWB & ES & FFP & PP & AP & CRY & FWB \\
\hline HBsAg & 0.00 & 0.00 & 0.00 & 0.00 & 0.00 & 4.88 & 0.00 & 0.00 & 0.00 & 0.00 & 0.00 & 4.88 \\
\hline Anti-HIV & 0.00 & 0.00 & 0.00 & 0.00 & 0.00 & 4.88 & 0.00 & 0.00 & 0.00 & 0.00 & 0.00 & 4.88 \\
\hline Anti-HCV & 0.00 & 0.00 & 0.00 & 0.00 & 0.00 & 5.20 & 0.00 & 0.00 & 0.00 & 0.00 & 0.00 & 5.20 \\
\hline Anti syphilis Ag & 0.00 & 0.00 & 0.00 & 0.00 & 0.00 & 6.63 & 0.00 & 0.00 & 0.00 & 0.00 & 0.00 & 6.63 \\
\hline Blood Bag & 0.00 & 0.00 & 0.00 & 0.00 & 0.00 & 9.20 & 0.00 & 0.00 & 0.00 & 0.00 & 0.00 & 9.20 \\
\hline Injector $* 3$ & 0.56 & 0.56 & 0.56 & 0.56 & 0.56 & 0.56 & 0.49 & 0.49 & 0.49 & 0.49 & 0.49 & 0.49 \\
\hline Cannula & 0.59 & 0.59 & 0.59 & 0.59 & 0.59 & 0.59 & 0.52 & 0.52 & 0.52 & 0.52 & 0.52 & 0.52 \\
\hline Gloves $* 10$ & 2.33 & 2.33 & 2.33 & 2.33 & 2.33 & 2.33 & 2.05 & 2.05 & 2.05 & 2.05 & 2.05 & 2.05 \\
\hline Hemogram & 1.95 & 0.00 & 0.00 & 0.00 & 0.00 & 1.95 & 1.72 & 0.00 & 0.00 & 0.00 & 0.00 & 1.72 \\
\hline Cross match & 7.21 & 0.00 & 0.00 & 0.00 & 0.00 & 7.21 & 7.21 & 0.00 & 0.00 & 0.00 & 0.00 & 7.21 \\
\hline $\begin{array}{l}\mathrm{ABO}+\mathrm{Rh} \\
\text { determination }\end{array}$ & 5.91 & 0.00 & 0.00 & 0.00 & 0.00 & 5.91 & 5.91 & 0.00 & 0.00 & 0.00 & 0.00 & 5.91 \\
\hline Leukocyte filter & 0.00 & 0.00 & 0.00 & 0.00 & 0.00 & 59.10 & 0.00 & 0.00 & 0.00 & 0.00 & 0.00 & 52.11 \\
\hline ETDA tube $* 2$ & 0.29 & 0.00 & 0.00 & 0.00 & 0.00 & 0.29 & 0.25 & 0.00 & 0.00 & 0.00 & 0.00 & 0.25 \\
\hline Dry tube & 0.00 & 0.00 & 0.00 & 0.00 & 0.00 & 0.21 & 0.00 & 0.00 & 0.00 & 0.00 & 0.00 & 0.21 \\
\hline Blood set & 1.11 & 1.11 & 1.11 & 1.11 & 1.11 & 0.00 & 0.98 & 0.98 & 0.98 & 0.98 & 0.98 & 0.00 \\
\hline Supply cost & 135.37 & 43.03 & 235.73 & 204.60 & 25.87 & 0.00 & 135.37 & 43.03 & 235.73 & 204.60 & 25.87 & 135.37 \\
\hline Total & 154.51 & 47.07 & 239.77 & 208.64 & 29.91 & 101.25 & 155.32 & 47.61 & 240.31 & 209.19 & 30.45 & 108.92 \\
\hline
\end{tabular}

ES: Erythrocyte suspension; FFP: Fresh frozen plasma; PP: Pooled platelets; AP: Apheresis platelet; CRY: Cryoprecipitate; FWB: Fresh whole blood; HBsAg: Hepatitis B surface Antigen; Anti HIV: Anti Human Immunodeficiency Virus Antibody; Anti HCV: Anti Hepatitis C Virus Antibody; ETDA: Ethylenediaminetetraacetic acid.

2. Material cost: The added material is calculated by adding the tests and process costs, making any of the components ready for transfusion over the cost of obtaining the supplied component.

3. Labor cost: During the blood transfusion process, six different personnel are employed, namely nurse, perfusionist, clinician doctor, co-doctor, and porter. The total time each staff participated in the transfusion process is calculated on average by observation and labor costs per min are estimated.

4. General production cost: The general production costs for each blood component include municipal water, fuel and electricity

Table 2. Labor time and expenses

\begin{tabular}{|c|c|c|c|c|c|c|c|c|}
\hline & \multicolumn{6}{|c|}{ Working time (min) } & \multicolumn{2}{|c|}{ Cost per $\min (\$ / U S D)$} \\
\hline & ES & FFP & PT & $\mathrm{AP}$ & CRY & FWB & 2018 & 2019 \\
\hline Nurse & 55 & 30 & 30 & 30 & 30 & 55 & 0.54 & 0.60 \\
\hline Perfusionists & 10 & 10 & 10 & 10 & 10 & 10 & 0.56 & 0.62 \\
\hline Anesthesiologist & 10 & 10 & 10 & 10 & 10 & 10 & 1.31 & 1.44 \\
\hline Clinician doctor & 10 & 10 & 10 & 10 & 10 & 10 & 1.76 & 1.95 \\
\hline Assistant doctor & 10 & 10 & 10 & 10 & 10 & 10 & 0.80 & 0.88 \\
\hline Porters staff & 25 & 25 & 25 & 25 & 25 & 25 & 0.40 & 0.44 \\
\hline The total time & 120 & 95 & 95 & 95 & 95 & 120 & & \\
\hline 2018 Unit labor fee $(\$)$ & 83.90 & 70.40 & 70.40 & 70.40 & 70.40 & 83.90 & & \\
\hline 2019 Unit labor fee $(\$)$ & 92.59 & 77.69 & 77.69 & 77.69 & 77.69 & 92.59 & & \\
\hline
\end{tabular}

ES: Erythrocyte suspension; FFP: Fresh frozen plasma; PT: Pooled platelet; AP: Apheresis platelet; CRY: Cryoprecipitate; FWB: Fresh whole blood. 


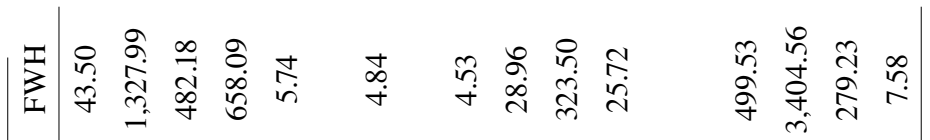

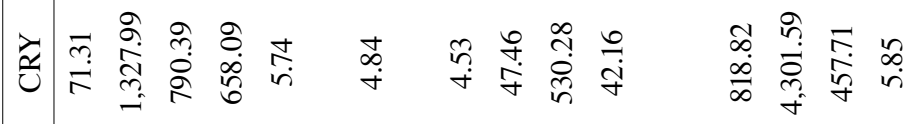

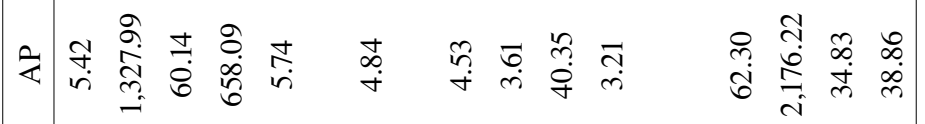
ฉे

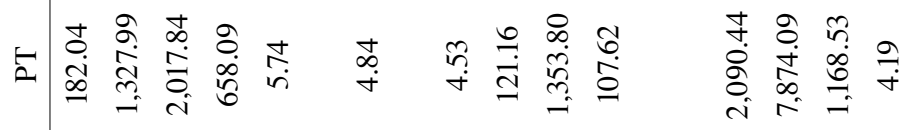

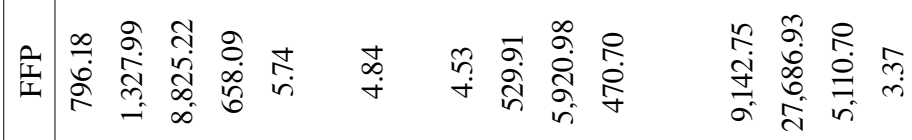

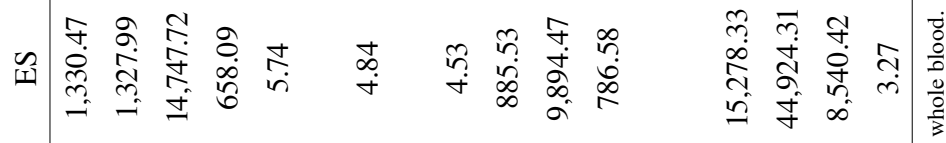

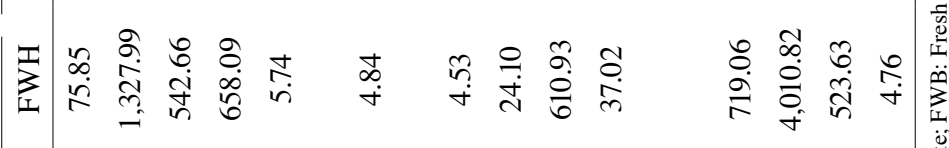

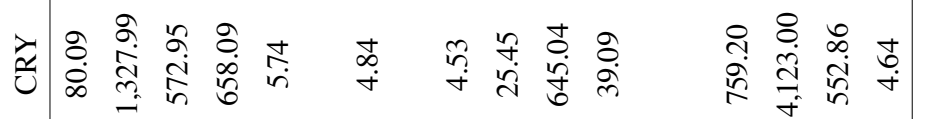

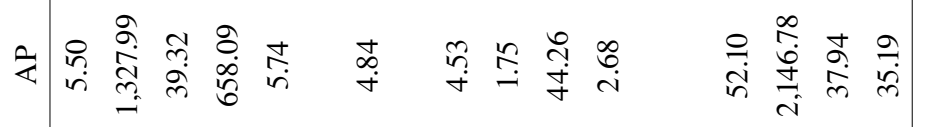
$\stackrel{\infty}{\stackrel{2}{\pi}}$

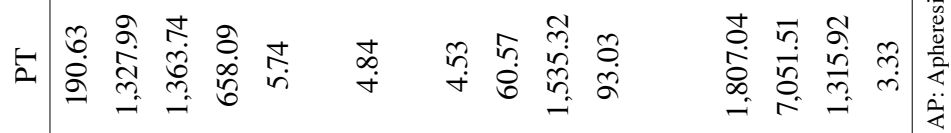

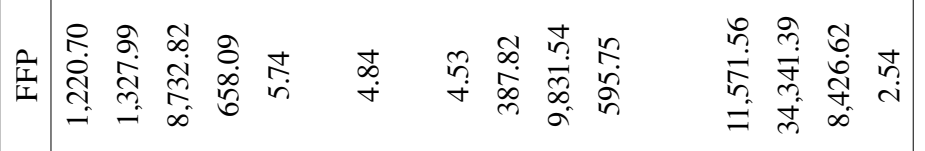

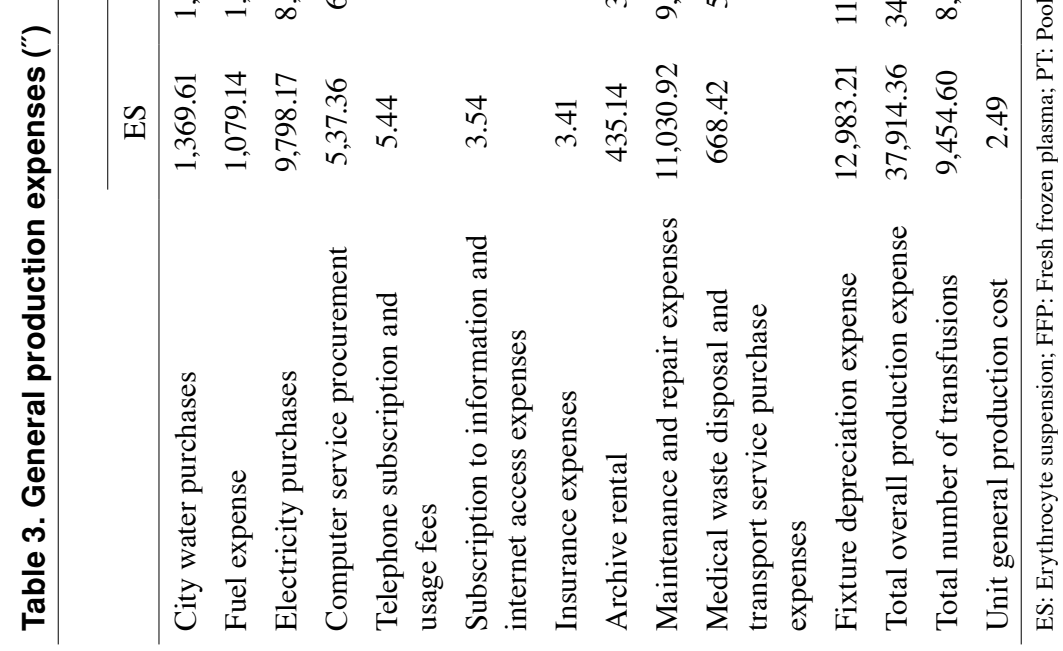


consumption, computer service purchase fee, telephone subscription fees, information subscription, and internet access fees, computer service purchase expenses, insurance expenses, medical waste, disposal and shipping service expense, archive rental expense, and depreciation expense.

The one-year total cost obtained from the hospital accounting information system was first assigned to the transfusion center and, then, to six different blood components processed in the transfusion center. Electricity, water, and fuel expenses are distributed based on the per $\mathrm{m}^{2}$; computer service purchase expense, telephone subscription fee, information and internet access fee, insurance expense, archive leasing expense were distributed based on the total number of staff working in the blood center (10 employees). Inventory depreciation expense was calculated as $20 \%$ of the monetary value of inventory in accordance with the notification of the General Directorate of Accounting of Turkey. ${ }^{[9]}$ Healthcare centers pay a fee for medical waste management with a varying cost per $\mathrm{kg}$ of the medical waste. Therefore, the amount of medical waste generated by the blood center in one year was proportioned to the total medical waste amount $(\mathrm{kg})$ of the hospital for one year and this rate was applied to the expense (") of the total medical waste disposal and transportation service.

After the total production costs of the blood center were calculated in this way, general production costs (variable costs such as electricity, water, maintenance and repair, medical waste disposal and transportation service and depreciation costs) were distributed according to the ratio of six different blood components in the total number of transactions. Since fuel, computer service purchase, telephone, information and internet access, insurance and archive rental expenses were independent of production amount, they were distributed equally to these six different blood components. Unit costs for each blood component for 2018 and 2019 were calculated separately by collecting unit acquisition costs, material costs, labor costs, and general production expenses.

\section{RESULTS}

Calculated costs for blood component supply, materials and testing to prepare the units for transfusion are shown in Table 1.

The FWB donation was done in our center. Other blood components fees underwent additional tests and processes for transfusion. There was no change in the fees paid to Turkish Red Crescent in 2018 and 2019.

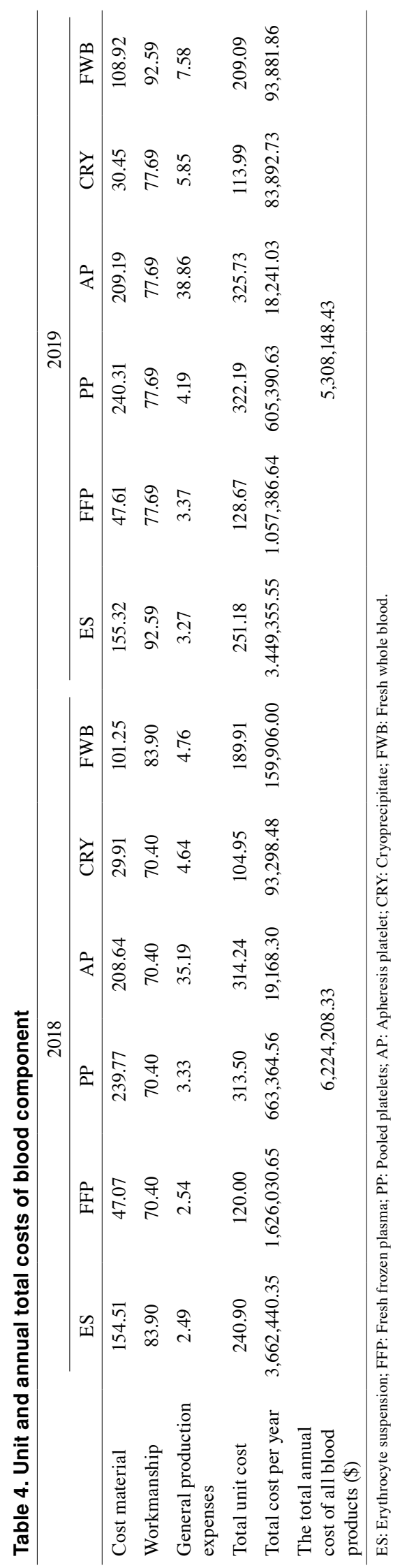


Table 5. Change in the number of inpatients, catheters, procedures, surgery and blood components in 2018 and 2019

\begin{tabular}{lccc}
\hline & 2018 & 2019 & Variation (\%) \\
\hline Inpatient & 22,444 & 22,270 & -0.78 \\
Catheter procedure & 24,495 & 20,413 & -16.67 \\
Surgery & 3,951 & 4,234 & 7.16 \\
Erythrocyte suspension & 15,203 & 13,733 & -9.67 \\
Fresh frozen plasma & 13,350 & 8,218 & -38.45 \\
Pooled platelet & 2,116 & 1,819 & -14.04 \\
Apheresis platelet & 61 & 56 & -8.2 \\
Cryoprecipitate & 889 & 736 & -17.22 \\
Fresh whole blood & 842 & 449 & -46.68 \\
Total blood product & 32,661 & 25,071 & -23.24 \\
\hline
\end{tabular}

The highest supply cost for both years was in the PT and AP.

The time and labor expenses involved in the performance of each activity in the transfusion chain are shown in Table 2. The cost per min of each staff was calculated by dividing the annual total wages by the total working min per year. Approximately $20 \%$ of the daily work of the staff went through rest and breaks. Taking into account the total number of workdays and idle time in 2018 and 2019, total working times were calculated as 96,000 and 95,232 min, respectively.

During the transfusion process, staff were involved in six different roles. Costs per min were calculated (Table 2). Labor expenses were higher in the FWB and ES components, due to the long transfusion times.
The unit cost per share of blood components from the general production expenses to the transfusion center is shown in Table 3. The relatively low number of AP transfusions caused the unit general production costs to be higher than other blood components. Compared to 2018, the decrease in the number of transfusions of all blood products in 2019 caused the general production expense per unit product to be calculated higher.

Unit and total annual costs of each blood component calculated are shown in Table 4. While the highest blood transfusion unit cost was AP, ES was the highest total transfusion cost per year.

The fact that the number of transfusions of the AP in a year was very low, compared to other components, it caused the unit cost to be charged

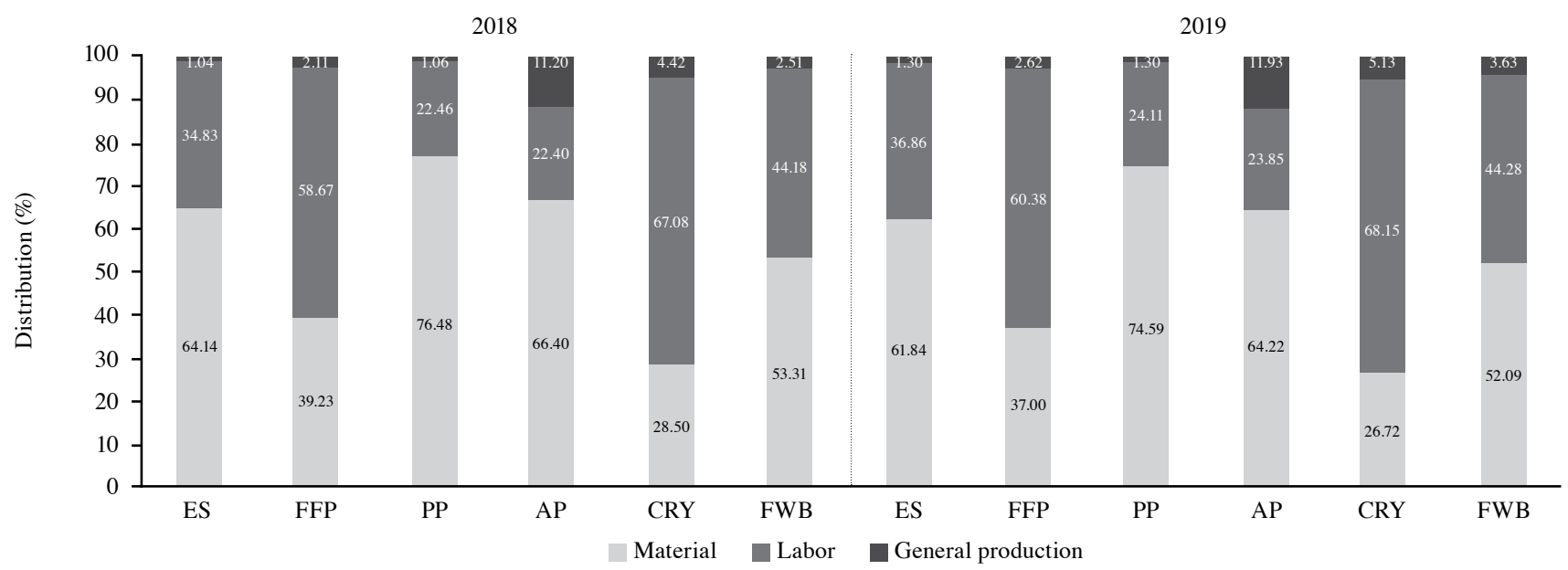

Figure 1. Distribution of unit costs of blood components.

ES: Erythrocyte suspension; FFP: Fresh frozen plasma; PP: Pooled platelets; AP: Apheresis platelet; CRY: Cryoprecipitate; FWB: Fresh whole blood. 
from the fixed expenses to be high. The supply cost for 2019 was $53.89 \%$ of the total unit cost in FWB and ES, $33.44 \%$ in FFP, $73.16 \%$ of the PP, $62.81 \%$ of the AP, and $22.69 \%$ of the CRY. In 2018, similar rates were obtained. The number of blood components used in 2019 decreased by $23.24 \%$, compared to 2018 with the implementation of the new blood management model, although the unit blood component costs increased, \$916,059.90 (14.71\%) were saved in the annual cost of all blood components. The reduction in components, number of patients, operations, and procedures are shown in Table 5.

The distribution of items constituting the total unit cost of blood components did not differ significantly in 2018 and 2019 (Figure 1). While the most important part of the total cost (58.67\% and $67.08 \%$, respectively) in FFP and CRY were the labor costs, the AP had the highest general production expense ratio. The component with the highest ratio of direct material cost in total cost was PP.

\section{DISCUSSION}

This study demonstrated the unit cost of all processes starting with the supply of six different blood components and continuing up to transfusion. The study also compared the impact of the reduction in annual transfusion costs for process improvement with the hybrid costing method. The main findings of the study were that: We calculated the total transfusion cost of one unit of blood composition and showed the savings achieved by improving the transfusion quality process.

Transfusion process improvement work reduces the economic burden of blood transfusion. Hospitalization, medical care and drug costs, such as the annual cost of blood transfusion in Turkey are estimated as at least 100 million Dollars. ${ }^{[10]}$

Estimated the cost of blood transfusion in the Western Europe with six different study findings, taking into account direct costs, the average cost was set at 878 Euros $(€) \cdot{ }^{[11]}$ Evaluating the full cost of blood transfusion in the United Kingdom National Health Service (NHS) with micro-costing, laboratory, nursing inputs, and waste were identified as three components of the total cost of blood management. ${ }^{[12]}$ The average cost per transfused blood component was calculated as $\$ 70.52$ for ES, $\$ 84.10$ for PLT, $\$ 55.22$ for FFP, and $\$ 71.58$ for CRY. In another study conducted in England, the cost of annual blood transfusion to the NHS was $£ 635$ for ES, $£ 378$ for FFP, $£ 347$ for PP, and $£ 834$ for CRY. In our study, the cost was calculated as $\$ 251.18$ for ES, \$128.67 for FFP, \$322.19 for PP, \$325.73 for
AP, \$113.99 for CRY, and \$209.09 for FWB. Although the calculation methods in these studies are similar, the difference in cost perspective and the factors included in the cost led to different unit costs. In most of the studies, procurement cost, labor cost, and material cost are common cost elements. ${ }^{[13,14]}$

An eight-stage costing model was created for the use of ES in Canada and personnel, material, and capital equipment costs were evaluated using activity-based costing principles at each stage of the transfusion. Unit ES total hospital cost was found to be $\$ 243,1$. Labor cost was calculated as $77.5 \%$ and material cost as $19 \%$. $^{[15]}$

Another study using activity-based costs of blood transfusion in surgical patients reported the cost to be 3.2 to 4.8 times higher than the cost of blood procurement. ${ }^{[16]}$ The average cost per patient was $\$ 219$, with storage, testing, and other additional costs for blood components purchased an average of \$155. About $37 \%$ of the total cost was the procurement cost, while $13 \%$ was the storage cost, $43 \%$ was the laboratory testing, and $7 \%$ was the blood management. ${ }^{[17]}$

In a study where the cost of plasma transfusion was calculated using an activity-based cost method, unit cost per FFP was found to be $\$ 409$, while the unit cost per patient transferred was $\$ 1,608$. Waste products, in-hospital processes, and overhead costs were found to account for $89 \%$ of total FFP transfusion costs. ${ }^{[18]}$

In this study, we determined that the cost of supply varies according to blood component which constituted approximately 22 to $73 \%$ of the total cost. Labor and general production expenses constituted $63 \%$ of the total cost in the unit cost of FFP. It is thought that the uncalculated cost of wasted components may play a lower role than other studies. Also, lower labor costs in other studies may have an impact on lower hospital costs. The average minimum wage in OECD countries in 2018 was $\$ 12,616$ and $\$ 15,410$ in Turkey. ${ }^{[19]}$ In other studies, the cost of providing one unit of blood to the hospital is often higher than our study, which affects the overall cost to remain relatively low.

With the transfusion process improvement studies carried out in 2019, a decrease of $23.24 \%$ in the number of transfusions and a saving of approximately $15 \%$ $(\$ 916,059.90)$ in total transfusion cost was achieved, although the unit transfusion cost increased compared to 2018 .

Failure to generalize the results obtained by performing the analysis on a certain population is an inherent limitation of the micro-costing method. ${ }^{[20]}$ Conducting the study in a single-center is another 
limitation. However, the number of data, the number of patients, and the number of blood components used in this study are high. Future multi-center studies may yield more useful data in terms of generalizability of the calculated costs. The scope of this article is the cost issue only, as improving the transfusion process is a subject of another research and should be prepared specifically for each hospital. ${ }^{[21]}$

In conclusion, transfusion causes an economic burden for both the hospital management systems and the country. To accurately calculate and manage this economic burden, it is extremely important to identify the unit cost of each blood component. In this study, we calculated the cost of transfusions in Turkey. Further studies analyzing the calculated cost from a social perspective are needed to obtain more comprehensive results.

\section{Declaration of conflicting interests}

The authors declared no conflicts of interest with respect to the authorship and/or publication of this article.

\section{Funding}

The authors received no financial support for the research and/or authorship of this article.

\section{REFERENCES}

1. Ağırbaş İ, Gök H, Akbulut Y, Önder ÖR. Hastanelerde maliyet analizi ve tıbbi rehabilitasyon hizmetlerinde birim maliyet hesaplanması. Türk Fiz Tip Rehab Derg 2012;58:103-8.

2. Shepard DS, Hodgkin D, Anthony YE. Analysis of hospital costs: a manual for managers. Prepared for the Health Systems Development Program. Geneva; World Health Organization; 2000.

3. Menderes M, Ersoy K. Genel sistem kuramı ve sağlık sistemi, hastane sistemi ve hasta bakım alt sistemi. Editör: Seçim H. Eskişehir: Açıköğretim Fakültesi; 1995. s. 43-73.

4. Akca N, Somunoğlu İkinci S. Ankara'da yer alan özel bir sağlık işletmesinin finansal tablolarının oran analizi yöntemi ile değerlendirilmesi. İşletme Bilimi Dergisi 2014;2:111-26.

5. Hofmann A, Ozawa S, Farrugia A, Farmer SL, Shander A. Economic considerations on transfusion medicine and patient blood management. Best Pract Res Clin Anaesthesiol 2013;27:59-68.

6. Chapel JM, Wang G. Understanding cost data collection tools to improve economic evaluations of health interventions. Stroke Vasc Neurol 2019;4:214-22.
7. Welton JM, Jenkins P, Perraillon MC. A micro-costing or 'bottom-up' approach to measuring nursing costs using data from electronic health records. Nursing Economic 2018;36:46-8, 51.

8. Tarihçe. Available at: https://kosuyolueah.saglik.gov.tr/ TR,100443/tarihce.html. [Accessed: October 03, 2020].

9. Karar Sayı 2015/8196. T.C. Resmi Gazetesi, Available at: https://www.resmigazete.gov.tr/eskiler/2015/11/20151104-6. htm. [Accessed: October 03, 2020].

10. Oge T, Kilic $\mathrm{CH}$, Kilic GS. Economic impact of blood transfusions: Balancing cost and benefits. Eurasian J Med 2014;46:47-9.

11. Abraham I, Sun D. The cost of blood transfusion in Western Europe as estimated from six studies. Transfusion 2012;52:1983-8.

12. Stokes EA, Wordsworth S, Staves J, Mundy N, Skelly J, Radford K, et al. Accurate costs of blood transfusion: A microcosting of administering blood products in the United Kingdom National Health Service. Transfusion 2018;58:846-53.

13. Varney SJ, Guest JF. The annual cost of blood transfusions in the UK. Transfus Med 2003;13:205-18.

14. Burns KE, Haysom HE, Higgins AM, Waters N, Tahiri R, Rushford K, et al. A time-driven, activity-based costing methodology for determining the costs of red blood cell transfusion in patients with beta thalassaemia major. Transfus Med 2019;29:33-40.

15. Lagerquist O, Poseluzny D, Werstiuk G, Slomp J, Maier M, Nahirniak S, et al. The cost of transfusing a unit of red blood cells: A costing model for Canadian hospital use. ISBT Science Series 2017;12:375-80.

16. Shander A, Hofmann A, Ozawa S, Theusinger OM, Gombotz H, Spahn DR. Activity-based costs of blood transfusions in surgical patients at four hospitals. Transfusion 2010;50:753-65.

17. Forbes JM, Anderson MD, Anderson GF, Bleecker GC, Rossi EC, Moss GS. Blood transfusion costs: A multicenter study. Transfusion 1991;31:318-23.

18. Shander A, Ozawa S, Hofmann A. Activity-based costs of plasma transfusions in medical and surgical inpatients at a US hospital. Vox Sang 2016;111:55-61.

19. Health expanditure and financing. Available at: https://stats. oecd.org/Index.aspx?DataSetCode=SHA, [Accessed: August 14, 2020].

20. Xu X, Grossetta Nardini HK, Ruger JP. Micro-costing studies in the health and medical literature: Protocol for a systematic review. Syst Rev 2014;3:47.

21. Günaydın S, Spahn DR, Özışık K, Demir A, Aşkın G, Sert $\mathrm{DE}$, et al. Building a patient blood management program in a large-volume tertiary hospital setting: Problems and solutions. Turk Gogus Kalp Dama 2020;28:560-9. 